\title{
Pertunjukan Ronggeng Ketuk dan Topeng pada Upacara Ngarot di Desa Lelea Kabupaten Indramayu (Sebuah Kajian Interaksi Simbolik)
}

\author{
Lina Marliana Hidayat \\ Sekolah Tinggi Seni Indonesia (STSI) Bandung \\ Jl. Buah Batu No. 212 Bandung 40265
}

\begin{abstract}
Ngarot is a folk festival of Lelea village in Indramayu, West Java. The both of performances, Ronggeng Ketuk and Mask Dance, are those considered to have a symbolic relationship with the participants of the ceremony those are both of young men (Bujang) and women (Cuwene). It is the conception of the symbolic relationship that is interesting to be observed deeply.

This study uses qualitative method such as symbolic interactive theory approach. The relationship of the series of Ngarot ceremony is a symbolic system series that can not be separated from one to another.
\end{abstract}

Keywords: Ngarot, Ronggeng Ketuk, Topeng, symbolic interaction

\begin{abstract}
ABSTRAK
Ngarot merupakan pesta rakyat desa Lelea di Kabupaten Indramayu Jawa Barat. Dua pertunjukan yaitu Ronggeng Ketuk dan Topeng merupakan pertunjukan yang dianggap memiliki keterkaitan simbolik dengan peserta upacara yaitu Bujang (pemuda) dan Cuwene (pemudi). Gambaran keterkaitan simbolik itulah yang menarik untuk diamati lebih mendalam.

Penelitian ini menggunakan metode kualitatif dengan pendekatan teori interaksi simbolik. Hubungan rangkaian Upacara Ngarot merupakan rangkaian sistem simbol yang tak bisa dilepaskan antara satu dengan yang lainnya.

Kata kunci: Ngarot, Ronggeng Ketuk, Topeng, interaksi simbolik

\section{PENDAHULUAN}

Upacara Ngarot merupakan salah satu upacara rakyat di Kabupaten Indramayu Jawa Barat dan dilaksanakan satu tahun sekali. Biasanya event ini jatuh pada hari rabu pada bulan November atau Desember, atau tergantung kepada kemungkinan curah hujan, karena kaitannya yang erat dengan masyarakat sawah sebagai tanda

dimulainya upacara tanam padi. Kehadiran pertunjukan Ronggeng Ketuk dan Topeng di dalam upacara Ngarot merupakan peristiwa seni yang menarik untuk dikaji.

Kehadiran dua pertunjukan tersebut dianggap masyarakat Lelea sebagai media interaksi antar pelaku upacara. Realitanya kedua pertunjukan tersebut tidak dapat dipisahkan satu dengan yang lainnya, karena merupakan kesatuan simbol yang
\end{abstract}


berpasangan. Pertunjukan Ronggeng Ketuk disimbolkan sebagai perempuan sedangkan pertunjukan Topeng sebagai simbol laki-laki. Pada upacara Ngarot pertunjukan Ronggeng Ketuk ditonton oleh pemuda (bujang) sedangkan pertunjukan Topeng di tonton oleh pemudi (cuwene).

Kajian ini mengambil perspektif teori interaksi simbolik. Penggunaan metode ini memungkinkan untuk mengungkapkan fakta, tidak saja dari sisi pengalaman indrawi yang logis dan etis, tetapi juga sifatnya yang transendental. Pada sisi lain, kedua pertunjukan tersebut, dalam pelaksanaannya memiliki daya tarik visual, baik dilihat dari warna-warna yang dipakai dalam asesoris dan kostum yang dikenakan oleh pemudi (cuwene) dan pemuda (bujang) sebagai peserta upacara maupun perlengkapan yang dikenakan oleh peserta. Begitu pula pertunjukan Ronggeng Ketuk dan Topeng, serta tanggapan-tanggapan yang spontan dari para penontonnya.

Berkaitan dengan hal itu, makna simbol seni pertunjukan Ronggeng Ketuk dan Topeng dalam upacara Ngarot tidak lepas dari apa yang disebut 'teks' dan 'konteks' pertunjukan. 'teks' adalah pertunjukan itu sendiri dengan segala macam kelengkapannya, sedangkan 'konteks' adalah wilayah-wilayah yang memiliki hubungan dengan 'teks', seperti tempat kejadian (peristiwa), atau ruang dan waktu. Hubungan 'teks' dan 'konteks' disatukan oleh proses interaksi simbolik para pelakunya secara holistik.

Hal tersebut sebagaimana diungkapan Blumer dalam Polloma (1984: 261):

Bahwa interaksionalisme simbolik dibangun maknanya oleh seorang aktor (pelaku). Premis utamanya mengisyaratkan bahwa; (1) manusia bertindak terhadap sesuatu berdasarkan makna-makna yang ada pada sesuatu itu bagi mereka; (2) makna tersebut berasal dari interaksi sosial seseorang dengan orang lain; (3) makna-makna tersebut disempurnakan di saat proses interaksi sosial berlangsung.
Upacara Ngarot bagi masyarakat desa Lelea merupakan upacara adat yang sangat penting. Biaya untuk kegiatan ini diperoleh dari hasil penjualan padi dari sawah Bengkok yang luasnya dua hektar di blok Tambangraga, yaitu sawah yang diwariskan oleh Buyut Kapol, dan dari swadaya masyarakat secara patungan.

Sebelum kegiatan upacara Ngarot dilaksanakan, masyarakat Lelea memiliki rangkaian upacara pertanian yang sambung menyambung dan tidak boleh terlewat, seperti Ngunjung Buyut (berkunjung ke makam leluhur), Sedekah bumi (syukur bumi) bertempat di sawah warisan Buyut Kapol. Mereka berkumpul untuk menetapkan waktu dan tanggal pelaksanaan upacara Ngarot. Penentuan waktu ini ditentukan berdasarkan kesepakatan bersama. Sejak itu bagi masyarakat desa Lelea yang memiliki pemudi (cuwene) dan pemuda (bujang) sudah harus mempersiapkan diri, terutama seragam pakaian upacara untuk anak-anak mereka. Tampaknya jarak satu bulan dari sejak kegiatan Sedekah bumi sampai pada pelaksanaan Ngarot, cukup waktu bagi masyarakat Lelea yang akan turut serta dalam kenduri sebelum musim tanam tiba tersebut, untuk mempersiapkan kelengkapan pakaian, biaya sawer dan lain-lainnya

Pada malam harinya, sebelum upacara Ngarot dimulai, diadakan pertunjukan Jidor di rumah Kuwu (kepala desa). Tujuannya untuk menghibur masyarakat sekaligus untuk bersilaturahmi. Pertunjukan Jidor sebagai hiburan berakhir sekitar pukul 24.00 WIB tengah malam.

Mulai pukul 6.00-8.00 WIB pelaksanaan Ngarot disiapkan di rumah Kuwu, para peserta upacara Ngarot berkumpul dengan tertib, khususnya bagi para cuwene dan bujang yang akan mengikuti upacara. Mereka terikat oleh persyaratan-persyaratan tertentu, yaitu: 1) merupakan muda-mudi penduduk asli Lelea; 2) muda-mudi yang 
benar-benar suci (belum pernah kawin/belum berumah tangga; 3) muda mudi yang benar-benar sukarela (Nalan, 1999: 29). Selain itu peserta upacara melibatkan pula aparat desa dan keluarga, demikian juga dengan para seniman pengisi acara untuk upacara tersebut.

Bagi para cuwene yang akan mengkuti upacara Ngarot sebelumnya diharuskan ngasrep (puasa tak makan garam) selama 5 hari agar terlihat bersih dan cantik; begitu juga dengan periasnya. Bagi peserta upacara Ngarot khususnya para muda-mudi harus sudah mempersiapkan segala keperluannya, seperti mempersiapkan busana dan Kaprabon (hiasan kepala) berupa rangkaian bunga yang terdiri dari cempaka kuning (michelia champaca), kenanga (cananga odorata), pudak (pandan), karnium, dan melati. Para cuwene diwajibkan pula menggunakan perhiasan seperti kalung, giwang dan cincin. Perhiasan ini tidak harus milik pribadi tetapi dapat meminjam dari keluarga. Pemakaian perhiasan yang sangat berlebihan ini disengaja agar peserta memiliki kesan lebih terpandang, menarik dan cantik, dengan warna keemasan; perhiasan yang dikenakan oleh para cuwene melambangkan keagungan. Sebagian masyarakat khususnya para orang tua menganggap para cuwene sebagai simbol bidadari. Bidadari yang turun ke bumi yang sering disebut sebagai bidadari patang puluh (empat puluh).

Upacara diawali dengan pidato Kuwu, dilanjutkan dengan pemukulan gong pertanda upacara dimulai ${ }^{1}$ yang dilanjutkan dengan prosesi upacara penyerahan perlengkapan pertanian. Usai prosesi pertunjukan Ronggeng Ketuk dan Topeng pun di mulai. Sebelumnya, para nayaga dua pertunjukan ini melakukan tatalu (gending kratagan) dalam waktu yang bersamaan. Tatalu yang biasanya diiringi dengan senggak (vokal) menandakan pertunjukan segera dimulai.

\section{HASIL DAN PEMBAHASAN}

\section{Pertunjukan Ronggeng Ketuk pada Upa- cara Ngarot}

Masyarakat Indramayu pada umumnya mengenal Ronggeng Ketuk saat dipertunjukkan pada upacara Ngarot sebagai sarana hiburan dan upacara. Ronggeng Ketuk, menjadi bagian yang tidak terpisahkan dengan para bujang. Dalam kaitan ini ronggeng berperan tidak hanya sebagai penghibur, namun dibalik itu, menurut masyarakat setempat, dipercaya sebagai dukun/syaman. Ronggeng dapat digolongkan pula sebagai syaman mediamik, penghubung ke dalam roh dan umumnya seorang perempuan (Makruf, 1966: 157). Anggapan demikian mempengaruhi kesadaran seseorang ketika mempersiapkan dirinya menjadi ronggeng di dalam sebuah upacara, seperti halnya dalam Ngarot.

Sebagaimana dituturkan Riwen seorang Ronggeng Ketuk bahwa setiap akan mengikuti upacara Ngarot, dirinya telah mempersiapkan diri dengan berpuasa selama tiga hari tujuannya untuk diberi kelancaran oleh Allah SWT, dan juga supaya disenangi oleh penonton. Kira-kira pukul 07.00 WIB, para nayaga memainkan musik pembuka (tatalu) yang berlangsung kira-kira selama 30 menit. Seiring tatalu berjalan, Riwen berdandan, dia memakai sanggul dengan polesan tata rias cantik, baju kebaya, kain batik, selendang dan asesoris lainnya. Fungsi selendang pada ronggeng, selain untuk kelengkapan dalam menari, juga dapat digunakan untuk 'alat menggaet' lawan jenis untuk menari bersama dengan cara mengalungkan ke lehernya. Riwen menghampiri panggung dan duduk, lalu langsung membawakan beberapa lagu. Kecuali lagu kidung, lagu-lagu lainnya diminta penonton laki-laki yang menari bersama sang ronggeng; biasanya mereka meminta lagu-lagu dangdutan. Penonton yang menari bersama ronggeng bukan hanya bujang 


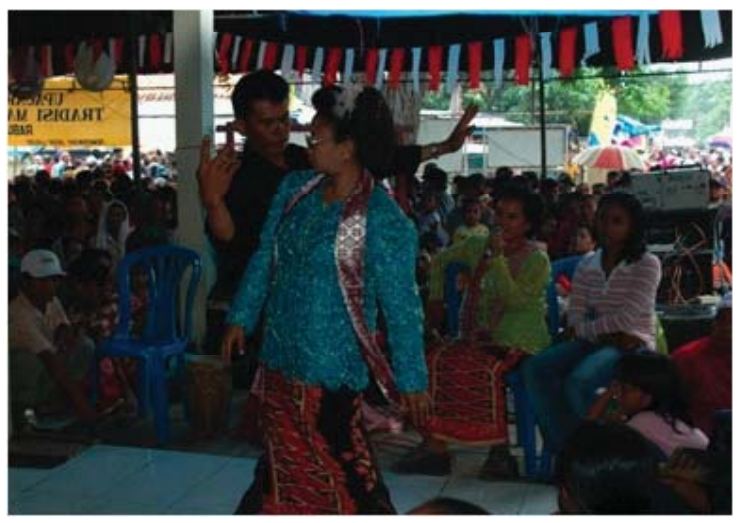

Gambar 1

Pertunjukan Ronggeng Ketuk pada upacara Ngarot

(Foto: Dokumentasi Lina Marliana, 2005)

(pemuda) namun para penonton pun dapat ikut menari bersama ronggeng tersebut. Ketika lagu selesai, ronggeng menghampiri para penonton yang telah menari bersama, untuk meminta imbalan berupa uang yang diberikan melalui jabat tangan. Hal lain yang menarik ketika para orang tua dari bujang, segera menyediakan uang untuk mempersiapkan saweran berikutnya, apabila anaknya kehabisan uang untuk ronggeng. Mereka punya keyakinan kalau memberi saweran yang banyak pada ronggeng pasti hasil panen akan berlimpah.

Dalam 'konteks' upacara Ngarot terdapat kepercayaan masyarakat setempat apabila bujang telah menari dengan ronggeng, mereka dianggap sudah dewasa. Pertunjukan Ronggeng Ketuk dapat dianggap sebagai ajang pendewasaan para bujang sekaligus menjadi hiburan para penonton lainnya.

\section{Pertunjukan Topeng pada Upacara Ngarot}

Sekitar pukul 9.30 WIB pertunjukan Topeng dimulai, para nayaga melakukan tatalu (gending kratagan) yang sangat keras dan diiringi dengan vokal bersahutan (senggak) para nayaga menandakan kepada masyarakat bahwa pertunjukan Topeng akan dimulai.

Dalang Topeng Carpan dari desa Cikedung sebelum menari biasanya melakukan

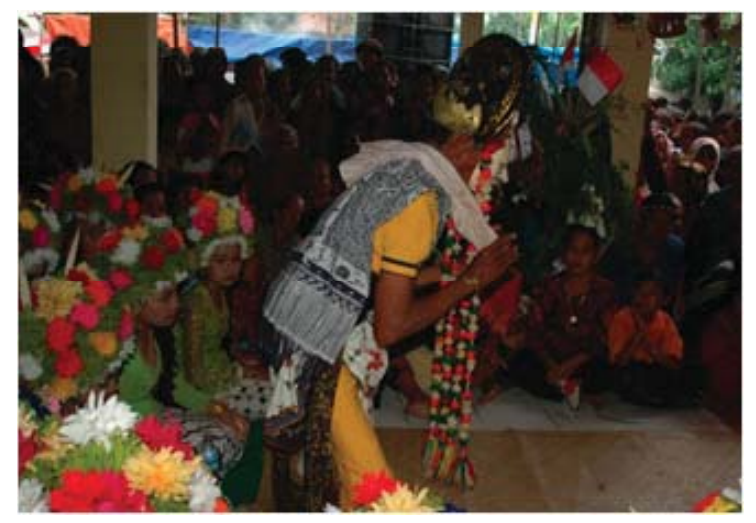

Gambar 2

PertunjukanTopeng pada upacara Ngarot (Foto: Dokumentasi Marliana, 2005)

puasa selama tiga hari, tujuannya agar diberi kelancaran dalam pertunjukan, agar menarik dimata penonton. Dalang Carpan menyediakan sesajen, yang disimpan dekat ancak kendang dilanjutkan dengan membakar kemenyan. Dalang Topeng Carpan mulai berdandan di dekat kotak dengan memakai kostum lengkap. Kemudian mempersiapkan kedok yaitu kedok Panji, Pamindo putih, Tumenggung, Rumyang dan Klana. Masingmasing kedok dibungkus dengan ules (kain pembungkus kedok) dan diletakkan secara teratur, serta tekes/sobrah yang di letakkan di atas kotak.

Setelah Dalang Topeng mengenakan kostum lengkap, ia langsung duduk bersila, kepala menunduk, dahi menempel ke kotak menghadap ke sebelah Timur. Posisi seperti ini menunjukkan bahwa ia sedang mengucapkan doa-doa untuk memohon kepada Yang Maha Kuasa dan kepada para leluhur. Dalang Topeng kemudian secara perlahan berdiri menarikan tari yang pertama yaitu tari Topeng Panji, kedua Topeng Pamindo/Samba yang disebut Pamindo Gimbal. Pada tarian Topeng Pamindo terdapat aktivitas saweran uang kertas dan uang logam, beberapa di antaranya dibungkus saputangan atau selendang, dan ada juga yang langsung diletakkan di rantang, terutama oleh orangtua para cuwene. Setiap saputangan atau selendang, sebelum dikemba- 
likan kepada para pemberi sawer, terlebih dahulu oleh Dalang Topeng diberi minyak wangi dan mantra-mantra. Tampak juga para penonton perempuan yang mayoritas orang tua meminta sampur yang dipakai Dalang Topeng, setelah ia melakukan saweran untuk diulaskan kemukanya supaya mendapat berkah dan didoakan oleh Dalang Topeng agar panennya berlimpah. Selanjutnya tari yang ketiga adalah tari Topeng Tumenggung. Kemudian disusul dengan tari keempat yaitu tari Topeng Rumyang dan diakhiri dengan tari Topeng Klana (Rahwana) dengan gerakan tarinya yang sangat gagah, kuat, dan dinamis.

Pertunjukan Topeng merupakan pertunjukkan terakhir pada upacara Ngarot. Sampai hari ini masyarakat menganggap bahwa Dalang Topeng sebagai syaman (dukun); karena itu selesai pertunjukan biasanya masyarakat mendekatinya dengan beberapa tujuan, misalnya meminta anaknya cepat sembuh dari penyakitnya, meminta nama untuk anaknya yang baru lahir, serta minta doa agar mendapat berkah dan panen yang akan datang berlimpah, dan lain-lain.

\section{Kajian Interaksi Simbolik pada Individu dan Masyarakat Lelea dalam Pra dan Pasca Upacara Ngarot}

West dan Turner (2007) menyampaikan tujuh asumsi tentang interaksi simbolik. Asumsi West dan Turner dipergunakan sebagai perspektif kajian tentang interaksi simbolik, sebagai berikut:

(1) Tindakan manusia memiliki makna yang sama dengan yang lainnya; (2) Makna dihasilkan dari interaksi di antara masyarakat; (3) Makna dimodifikasi melalui proses interpretasi; (4) Individu berhubungan-konsep diri melalui interaksi dengan yang lain; (5) Konsep diri menyediakan motif-motif tingkah laku; (6) Masyarakat dan kelompok-kelompok dipengaruhi oleh budaya dan proses sosial; (7) Struktur sosial terlihat melalui interaksi sosial.
Tujuh asumsi tentang interaksi simbolik tersebut akan digunakan untuk mengkaji dua pertunjukan (Ronggeng Ketuk dan Topeng) di dalam Upacara Ngarot.

1. Tindakan manusia memiliki makna yang sama dengan yang lainnya

Bahasa adalah alat komunitas kultur untuk berkomunikasi dan tindakan berbahasa dapat disebut juga sebagai tindakan sosial yang memiliki makna yang sama karena dipahami oleh semua anggota masyarakat, dalam tataran usia yang sama maupun berbeda. Bahasa sehari-hari mereka adalah bahasa akrab dan tidak terlalu mengenal undak usuk basa atau pranata bahasa. Rasa hormat kepada yang lebih tua dan kepada pemimpin (Kuwu) lebih nampak dari bahasa non verbal mereka.

2. Makna dihasilkan dari interaksi di antara masyarakat

Apa yang dilakukan masyarakat desa Lelea merupakan peristiwa rangkaian kesadaran terhadap warisan. Rangkaian upacara, mulai dari Ngunjung Buyut yakni melakukan prosesi mengunjungi makammakam para leluhur mereka untuk berdoa bersama. Masyarakat mengetahui apa artinya kedudukan makam-makam leluhur yang mereka hormati dari satu generasi ke generasi lainnya. Mereka sebenarnya mengingat siapa diri mereka dan kemudian menyadarinya bahwa mereka punya asal usul. Kesadaran atas asal usul ini menghasilkan makna religiusitas bagi mereka. Dalam kaitan inilah mereka berdoa di tempat-tempat roh leluhur yang dipercaya menjaga desa mereka (sebagai guardian spirit) untuk mendapatkan berkah (barokah) atau istilah mereka adalah ngalap berkah yang memberi mereka sugesti untuk mengerjakan sawah secara baik supaya hasil panenannya baik pula. Makna Ngunjung Buyut terlihat dihasilkan dari interaksi di antara masyarakat yang mayoritas petani itu, tanpa melupakan kehadiran adanya kekuatan para 
Buyut sebagai Guardian spirit (mereka lebih merasa segan dan takut kepada para Buyut, kalau tidak melaksanakan Ngunjung Buyut). (Warson, wawancara: 2009).

3. Makna dimodifikasi melalui proses interpretasi

Masyarakat Lelea yang termasuk dalam kategori masyarakat 'kultur subjektif' merasa perlu menjaga sawah warisan Buyut Kapol. Sawah tersebut merupakan sawah leluhur (karuhun) yang sudah terbukti kesuburannya sampai sekarang dan telah menghasilkan panen yang selalu membantu masyarakat Lelea meningkatkan kesejahteraannya. Sawah warisan Buyut Kapol ini kalau ditilik dari rentang sejarahnya yang panjang. Sawah tersebut dipercaya dapat mendatangkan panenan yang melimpah, apabila dijaga dan dipelihara sesuai dengan perlakuan yang diwariskan secara turun temurun. Konsep perlakuan ini menjadi amanat bagi setiap Kuwu (kepala desa) di desa Lelea. Apabila seorang Kuwu tidak mampu menjaga sawah karuhun warisan Buyut Kapol tersebut, misalnya panenannya menurun bahkan gagal panen, artinya Киwи tersebut telah gagal dalam menjaga warisan leluhur sekaligus gagal pula menjadi Kuwu desa Lelea. Pilihan yang tepat menjadi seorang Kuwu adalahyang mampu mengemban amanat leluhur, yakni menjaga dan memelihara sawah Karuhun tersebut. Proses perlakuan terhadap sawah leluhur ini telah banyak dimodifikasi berdasarkan tafsir Kuwu dan masyarakat lainnya, sehingga tradisi Sedekah bumi (syukur bumi) menjadi penting sebagai langkah kedua dari rangkaian menuju hasil panenan yang berlimpah. Salah satu buktinya adalah pertunjukan Wayang Kulit setiap delapan tahun sekali dengan lakon Bumi Loka. Termasuk juga pemilihan binatang kebo (kerbau) yang akan dikurbankan; kerbaunya harus yang sehat, kuat, dan tidak cacat. Seorang ahli kebo diberi tugas untuk memilih kebo yang terbaik, karena akan dipersembahkan kepa- da leluhur mereka dengan penyatuan kebo sebagai binatang yang lekat dengan kesuburan sawah, supaya sawah menjadi boyor (gembur). Makna ini tentunya merupakan hasil modifikasi yang telah melalui proses interpretasi secara turun temurun. Pernah dalam suatu masa pemerintahan seorang Kuwu yang melakukan interpretasi sendiri (meskipun warga masyarakat kurang setuju), yakni binatang kurban untuk Sedekah bumi dari kerbau digantikan dengan sapi. Ternyata hasil panenan menurun dan akhirnya ketika mendapatkan Kuwu baru, yang kemudian bertekad mengembalikan hasil panenan dengan mengganti kembali binatang kurban dengan kerbau. Hasil panenan berlimpah, karenanya Kebo memang mereka percayai sebagai binatang kurban yang membawa kesuburan. Peristiwa pergantian 'kerbau' ke 'sapi' dan kemudian dilakukan sebaliknya, menunjukkan adanya makna yang dimodifikasi.Tetapi apabila makna yang dimodifikasi tersebut tidak dihasilkan melalui proses interpretasi bersama, atau hanya interpretasi individu yang kebetulan memiliki kekuasaan sebagai Kuwu, hasilnya tidak menggembirakan. Memang benar Kebo memiliki daging yang tidak seenak Sapi. Dalam kaitan ini persoalannya bukanlah pada masalah daging, namun terletak pada makna yang diwariskan, yakni Kebo identik dengan Boyor (gembur dan subur). Makna Kebo harus dipandang sebagai makna pemberi kesuburan berdasarkan tradisi masyarakat petani desa Lelea.

4. Individu berhubungan-konsep diri melalui interaksi dengan yang lain

Peranan seorang Kuwu telah terbukti tidak boleh melakukan interpretasi sembarangan terhadap makna yang diwariskan secara turun temurun. Ia harus berperan sebagai individu yang menjaga warisan turun temurun, sebagai pemimpin di dalam memelihara tradisi yang diwariskan, sebagai ujung tombak pewaris aktif dari warisan leluhur desa Lelea. Apabila seorang 
Kuwu mencoba melakukan interpretasi makna tidak berdasarkan tradisi yang sudah berjalan, di mana tindakan interpretasinya itu sebagai tindakan sosial yang berdampak pada pencapaian hasil panen (peristiwa kebo diganti sapi). Peristiwa ini mengembalikan kesadaran terhadap Kuwu penggantinya, bahkan secara pribadi Kuwu mengajak kembali seorang ahli binatang kebo untuk mencarikan kebo yang sehatdan tidak cacat. Dalam kaitan ini sebenarnya Kuwu telah mengembalikan keyakinan diri masyarakat bahkan memperkuat kepercayaan pada makna bahwa kebo sebagai pemberi kesuburan. Apakah individu (seorang Kuwu) tidak boleh melakukan interpretasi di dalam berhubungan dengan tradisi masyarakatnya yang sudah turun temurun? Sepanjang tidak mengubah keyakinan pencapaian hasil panen, seorang Kuwu memiliki kebebasan di dalam melakukan interpretasi terhadap perkembangan dinamika masyarakatnya, terutama dalam memelihara harapan masyarakat terhadap panenan yang melimpah. Untuk mendekatkan hubungan intensitas dirinya dengan masyarakat, seorang Kuwu membuka acara silaturahmi di rumahnya dengan memberikan hiburan gratis yakni pertunjukan Jidor lengkap dengan sinden dan saweran. Ternyata hal ini mendorong keakraban Kuwu dengan masyarakatnya, yang secara batiniah (kejiwaaan) dapat dipastikan akan melahirkan dorongan hati untuk lebih lebih meningkatkan semangat kerja demi berhasilnya panenan sawah-sawah mereka. Apabila hasilnya melimpah, maka mereka pun sejahtera. Kegiatan pertunjukan Jidor di rumah seorang Kuwu ini sebelumnya belum pernah ada.

5. Konsep diri menyediakan motif-motif tingkah laku

Seorang Kuwu sudah terbukti harus mampu membaca dinamika dan harapan masyarakatnya. Kalaupun dia melakukan interpretasi atau modifikasi mestinya tidak mengganggu batiniah masyarakatnya. Menjaga dan memelihara batiniah masyarakat adalah penting demi suksesnya program dirinya menjadi Kuwu yang berhasil (dalam pandangan masyarakat Lelea, Kuwu yang berhasil adalah Kuwu yang bisa meningkatkan hasil panenan sawah-sawah mereka menjadi berlimpah tiap tahunnya atau minimal sama dengan tahun sebelumnya). Apabila ini dapat dibuktikan oleh Kuwu tersebut maka akan ada jaminan dari masyarakat bahwa Kuwu tersebut dapat dipilih kembali dalam masa bakti selanjutnya. Kalau begitu, apa yang harus dilakukan seorang Kuwu supaya mendapat jaminan dipilih kembali dalam masa bakti berikutnya? Seorang Kuwu di Lelea harus memiliki konsep diri yang mampu menyediakan motif-motif tingkah laku yang sejalan dengan tradisi Lelea yang sudah berjalan turun temurun, terutama menjaga dan memelihara Sawah Karuhun warisan Buyut Kapol dengan segala rangkaian tradisinya, baik pra-Ngarot maupun pasca-Ngarot.

6. Masyarakat dan kelompok-kelompok dipengaruhi oleh budaya dan proses sosial

Tradisi Ngarot sejak awal sampai sekarang sesungguhnya telah mengalami proses invention of culture (budaya yang ditemukan) menurut kategori James Clifford. Budaya yang dijalankan secara turun temurun, tetapi senantiasa mencari kesempurnaan, baik di dalam pelaksanaannya maupun di dalam manifestasi simbolsimbol yang mengikutinya. Berdasarkan catatan-catatan di lapangan, seperti tradisi pada umumnya, di masyarakat Lelea keberadaan sawah karuhun warisan Buyut Kapol menjadi sentral peristiwa budaya Ngarot. Sejak awal telah dituturkan, bahwa Buyut Kapol mewariskan sawah miliknya untuk kemakmuran masyarakat desa Lelea sampai akhirnya dipelihara terus menerus dari satu generasi ke generasi.

Peristiwa Ngarot adalah bukti nyata dari adanya pengaruh budaya yang diwariskan 
dan dikembangkan melalui proses sosial masyarakat dengan kelompok-kelompok yang ada di dalamnya. Kelompok perangkat desa sebagai jajaran aparat pemerintahan yang menduduki struktur sosial secara formal dari pemerintah memiliki kewajiban formal mengelola desa sekaligus juga memiliki kewajiban melanjutkan budaya Lelea yang sudah terbukti memberi kemakmuran dan kesejahteraan bagi masyarakatnya. Kelompok masyarakat terutama para pewaris aktif (orang-orang tua) yang telah mengalami peristiwa $\mathrm{Nga}$ rot sejak muda (bahkan terdapat beberapa orang yang perjodohannya karena upacara Ngarot, yang pernah sebagai Cuwene atau Bujang). Kelompok ini salah satunya yang merasakan bahwa budaya Ngarot harus terus dipertahankan bahkan semakin disempurnakan. Proses sosial sangat mempengaruhi masyarakat Lelea untuk melakukan sosialisasi diri dengan masyarakat sekitar desanya, di mana desa mereka menjadi terkenal karena Ngarot. Ngarot bagi masyarakat sekitar dan luar Lelea adalah sebuah peristiwa yang memberikan kesempataan untuk melakukan interaksi sosial sekaligus ekonomi; oleh karenanya lapak-lapak yang berjejer di sepanjang kiri kanan jalan desa Lelea adalah peristiwa timbal balik sosial dan ekonomi yang ditunggu-tunggu setahun sekali.

7. Struktur Sosial terlihat dalam interaksi sosial

Ngarot sebagaimana sudah dijelaskan di paparan sebelumnya adalah pesta rakyat Lelea sebelum musim tanam tiba. Mereka sudah punya agenda kegiatan upacara praNgarot dan pasca-Ngarot. Keduanya menjadi rangkaian yang saling terkait dalam hubungan sosial dan spiritual. Peranan seorang Kuwu ternyata perannya tidak hanya secara formal sebagai kepala desa tetapi juga sebagai penjaga tradisi Lelea yang sangat menghormati guardian spirit Lelea yang dipercaya berada di makam-makam leluhur mereka yang turut melindungi keberhasilan panenan mereka. Seorang Kuwu akan merasa bersalah apabila tidak melaksanakan seluruh rangkaian pra- $\mathrm{Nga}$ rot dan pasca-Ngarot. Seorang Kuwu dapat dikatakan sebagai pelaku interaksi sosial yang melakukan komunikasi interaksi simbolik.

Selain Kuwu terdapat beberapa perangkat desa, seperti ulis dan lebe yang menjadi pemimpin pra-Ngarot dalam proses pengambilan air keramat dari makam-makam keramat; mereka dipercaya masyarakat Lelea memiliki kemampuan untuk melaksanakannya dan menjaga hasilnya. Perangkat desa lain adalah pamong desa yang menjadi juru bewara (yang memberi pengumuman) dengan berkeliling desa untuk menyampaikan tanggal pelaksanaan $\mathrm{Nga}$ rot dengan memukul bende (gong kecil).

Selain itu peranan ahli kebo yang memilih kebo yang sehat-kuat-tidak cacat, menjadi penting karena memerlukan keahlian tersendiri yang tidak bisa dilakukan semua orang. Walaupun Sedekah bumi yang dilengkapi dengan memotong kebo dilaksanakan setiap delapan tahun sekali, peranan ahli kebo tetap menjadi signifikan, karena dialah yang dianggap mampu memberikan keyakinan bahwa kebo yang dipotong layak untuk dipersembahkan pada tanah sawah warisan Buyut Kapol.

Selain kegiatan pra-upacara dan upacara Ngarot yang tidak kalah penting adalah, tumbuhnya profesi baru yakni perias $\mathrm{Cu}$ wene yang tahu benar seluk beluk pembuatan mahkota bunga yang disebut Kaprabon. Mereka ini asalnya dari orang tua gadis yang dulu pernah menjadi Cuwene atau dia sendiri pernah menjadi Cuwene. Memang tidak semua yang pernah menjadi Cuwene adalah perias Cuwene, karena sebagai perias mereka dituntut persyaratan kemampuan tertentu dengan puasa dan laku spiritual lainnya. Mengapa jadi tumbuh perias $\mathrm{Cu}$ wene? Karena dari tahun ke tahun peserta 
Ngarot yang menjadi Cuwene semakin banyak, mereka percaya semakin banyak $\mathrm{Cu}$ wene di dalam sebuah upacara Ngarot akan semakin memberikan kesuburan yang lebih baik. Hal ini terkait dengan mitos Cuwene yang dianggap sebagai titisan gambaran bidadari patang puluh yang akan memberikan kesuburan pada sawah-sawah mereka juga pada desa mereka.

Tidak bisa dilupakan adalah kesadaran yang tumbuh secara turun temurun dari para pemudi dan pemuda Lelea untuk menjadi peserta upacara Ngarot sebagai Cuwene dan Bujang. Kesadaran ini terkait dengan proses interaksi sosial sepanjang hidup mereka yang sejak kecil melihat upacara $\mathrm{Nga-}$ rot, di mana timbul hasrat ingin ikut karena dirias dan dimanjakan walaupun hanya sehari, tetapi berkesan sepanjang hidupnya. Mereka berharap dapat menemukan pacar atau kekasih bakal suami mereka. Buktibukti menunjukkan memang telah terjadi perkawinan di antara para Cuwene dan Bujang ini. Merekalah yang menjadi pendukung aktif upacara Ngarot karena sudah merasakan kemanjurannya; selain pesta sebelum tanam padi tiba, peristiwa ini juga telah mempersatukan jodoh mereka.

Peranan pemuda desa sebagai kelompok potensial yang kadangkala sering dianggap menjadi pengeruh suasana Ngarot, sepanjang kepemimpinan Kuwu Warson (sudah masuk dua periode menjadi Kuwu di Lelea) potensi pemuda diajak sebagai penjaga keamanan dengan memberikan kepercayaan mengelola lapak-lapak yang dijual kepada para pedagang yang datang dari luar dan berdagang sepanjang pesta Ngarot berlangsung. Hasilnya tidak terlalu dimasalahkan oleh Kuwu. Ia hanya ingin tahu saja dan pada dasarnya para pemuda tersebut ingin dilibatkan sebagai bagian dari pesta Ngarot. Memang upacara Ngarot berjalan lancar, pedagang berjualan dengan aman dan mengeruk untung, pemuda mendapat kepercayaan dan keuntungan pula tentunya.
Melihat interaksi sosial dari seluruh masyarakat Lelea di dalam menjalankan tradisi warisan leluhur mereka, struktur sosialnya pun dari masyarakat Lelea dapat terlihat dengan lebih jelas. Lebih tampak lagi pada kegiatan pasca-Ngarot yakni pada upacara Mapag Tamba dan Mapag Sri, menjadi bukti bahwa mereka menjadi pewaris aktif tradisi yang sudah turun temurun sekaligus dapat memetik hasilnya yang berlimpah.

\section{Kajian Interaksi Simbolik Pertunjukan Ronggeng Ketuk dan Topeng pada Upacara Ngarot}

Pada upacara Ngarot, pertunjukan Ronggeng Ketuk dan Topeng selalu tampil sebagai suatu keharusan. Kedua pertunjukan ini merupakan simbol berpasangan yang tidak dapat dipisahkan menurut kepercayaan masyarakat setempat. Pertunjukan Ronggeng Ketuk disimbolkan sebagai perempuan sedangkan Topeng disimbolkan sebagai laki-laki. Pada upacara Ngarot, pertunjukan Ronggeng Ketuk ditonton oleh pemuda (bujang) sedangkan Topeng ditonton oleh pemudi (cuwene)

Pertunjukan Ronggeng Ketuk dan Topeng dipilih sebagai pertunjukan yang berpasangan tapi berlawanan. Kehadirannya di tengahtengah upacara Ngarot dalam kesatuan ruang-waktu dan peristiwa secara bersamaan menimbulkan magi simpatetis sebagai kekuatan yang dipercayai akan mempengaruhi kesuburan lahan-lahan yang dimiliki oleh masyarakat. Secara visual dan kinetik, kedua pertunjukan tersebut mampu menciptakan interaksi simbolik terhadap apa yang disajikan dalam perhelatan budaya Ngarot tersebut.

Selain keberadaannya dalam upacara Ngarot sebagai pasangan sajian pertunjukan tersebut menghadirkan pula aktivitas interaksi simbolik di antara masyarakat penontonnya, misalnya terjadi kontak antara 
cuwene dan lanang yang saling berkomunikasi secara simbolik melalui kerlingan mata mereka yang menimbulkan ketertarikan antara keduanya. Aktivitas simbolik kaum muda-mudi tersebut tidak jarang berlanjut kejenjang hubungan percintaan sampai dengan perkawinan, sebagaimana yang dialami Carminah seorang pedagang sate yang mendapatkan jodoh pada waktu mengikuti upacara Ngarot tahun-tahun terdahulu (Carminah, wawancara: 2006).

Terdapat banyak makna yang ditangkap dari hadirnya kedua pertunjukan, Ronggeng Ketuk dan Topeng, dalam upacara Ngarot, yakni terdapatnya banyak simbol yang berinteraksi dalam upacara Ngarot, bukan saja sekedar simbol-simbol budaya namun juga simbol-simbol sosial dalam masyarakat. Secara kultural, simbol-simbol berinteraksi dalam peristiwa tersebut dengan kepercayaan dan pola pikir budaya masyarakat setempat. Demikian pula secara sosial, interaksi simbol terjadi antara penonton atau para peserta upacara Ngarot dan atribut sosial yang mereka kenakan.

Dalam simbol-simbol budaya, misalnya, sebelum dua pertunjukan dimulai pada upacara Ngarot, seorang Kuwu memberikan tanaman dan peralatan pertanian kepada peserta Ngarot, terutama kepada para pemuda (bujang). Tanaman yang diberikan berupa benih yang melambangkan bibit unggul, dan peralatan berupa cangkul dan arit sebagai peralatan utama serta ampel kuning (bambu kuning) dan daun andong supaya terhindar dari hama dan penyakit. Selanjutnya istri Kuwu memberikan air dalam kendi kepada para pemudi ( $\mathrm{Cu}$ wene) sebagai peserta Ngarot, yang melambangkan cukupnya air untuk keperluan kehidupan terutama dalam menggarap dan mengelola sawah-sawah mereka.

Pada simbol-simbol sosial dapat dilihat pada interaksi antara pelaku dan penonton dalam upacara Ngarot secara simbolik, misalnya dengan adanya keinginan penonton untuk melibatkan diri dalam pertunjukan Ronggeng Ketuk dan Topeng sebagai wujud aktualisasi diri. Interaksi simbolik dalam lingkup ini terjadi pula dalam pertunjukan Topeng yang ditonton oleh cuwene, di mana terjadi aktivitas saweran (menaburkan uang logam atau kertas) penonton yang mayoritas dilakukan oleh para orang tua cuwene. Aktivitas saweran yang dilakukan dengan melempar uang kearah penari Topeng tersebut merupakan suatu kebanggaan bagi orang tua para cuwene. Mereka mengeluarkan uang saweran sebanyak mungkin supaya berkesan bahwa dirinya menjadi wongsugih (orang kaya).

Selanjutnya, interaksi simbolik semakin terasa ketika kedua pertunjukan berlangsung pada upacara tersebut, misalnya interaksi antara Dalang Topeng dan penonton. Dalang Topeng bukan saja hanya sebagai penari, namun ia juga merupakan sosok terhormat, sosok perantara antara kekuatan transenden dan yang imanen. Ia adalah syaman yang memiliki kekuatan eficacy (kemanjuran) yang oleh masyarakat setempat dipercaya mampu menyembuhkan penyakit dan memberi berkah. Kedudukan seperti itu mendorong anggota masyarakat meminta Dalang Topeng memberikan nama anak atau cucu yang akan dilahirkan oleh orang tuanya. Sampai sekarang kepercayaan tersebut masih berlangsung dalam upacara Ngarot.

Selain hal tersebut, interaksi yang lebih bersifat simbolik dari cara pandang kebudayaan masyarakat petani lebih terlihat pada pertunjukan Ronggeng Ketuk. Antara penonton dan Topeng terjadi aktivitas simbolik dengan menari bersama. Gerakangerakan tari mereka yang erotis menunjukan bahwa aktivitas tersebut bukanlah seni pertunjukan demi erotisme, melainkan pertunjukan ritual kesuburan yang dasarnya adalah naluri religius (Sumardjo, 1992: 7).

Daya tarik kinetik yang ditampilkan oleh gerak-gerak penari Ronggeng Ketuk 
dan penari Topeng serta senggak-senggak berirama yang dilontarkan para nayaga kedua pertunjukan tersebut seolah-olah berinteraksi dalam suatu kosmos peristiwa budaya yang perlu diungkap pemahaman maknanya secara multiarah, multitafsir, dan multipersepsi. Di sisi lain terdapat aktivitas verbal berupa celotehan yang dilontarkan oleh kalangan penonton mengenai upacara Ngarot yang menjadikan peristiwa tersebut sebagai ajang kasinoman (generasi muda) tempat berinteraksinya muda-mudi dalam mencari jodoh. Hal ini diperkuat oleh banyak pendapat masyarakat daerah tersebut yang mengatakan bahwa seorang pemuda desa Lelea dianggap telah dewasa jika telah memiliki pengalaman menari dengan ronggeng atau pernah menjadi peserta dalam upacara Ngarot.

Intinya, bahwa pertunjukan Ronggeng Ketuk dan Topeng dalam upacara Ngarot merupakan media komunikasi yang menawarkan simbol-simbol sosial budaya masyarakat setempat. Bagi yang belum melihat pertunjukan tersebut ada kuriositas tersendiri karena pertunjukan tersebut hadir secara khusus dalam sebuah peristiwa budaya dengan waktu yang khusus, tempat yang khusus, dan para peserta yang khusus pula.

Pertunjukan Ronggeng Ketuk dan Topeng dalam upacara Ngarot ternyata tidak berdiri sendiri tetapi menjadi kesatuan yang saling terkait juga dengan upacara pra-Ngarot (Ngunjung Buyut dan Sedekah bumi) dan upacara pasca-Ngarot (Mapag Tamba dan Mapag Sri). Melihat upacara Ngarot ternyata tidak bisa hanya melihat pada kemeriahannya saja, tetapi juga pada apa yang ada di balik kemeriahan itu. Salah satu yang penulis amati dan kaji adalah interaksi simbolik dari prilaku masyarakat Lelea yang mendukung interaksi simbolik dua pertunjukan (Ronggeng Ketuk dan Topeng) pada saat berlangsungnya upacara Ngarot.

\section{PENUTUP}

Akhirnya penulis perlu menyimpulkan berupa asumsi asumsi, sebagai berikut:

1. Masyarakat Lelea dapat dikategorikan sebagai masyarakat kultur subjektif yang memiliki komunitas kultur yang khas.

2. Masyarakat Lelea menjalankan tradisi warisan leluhurnya dengan patuh dan dipimpin oleh seorang Kuwu.

3. Peranan seorang Kuwu sangat besar sebagai pemimpin desa maupun penjaga tradisi warisan yang harus dijalankan secara benar.

4. Kharisma dan spirit makam-makam Kabuyutan dipercaya masih memiliki kemanjuran (eficasy) karena dianggap sebagai guardian spirit (roh penjaga) bagi berlangsungnya proses interkasi simbolik dalam upacara pra-Ngarot (Ngunjung Buyut dan Sedekah bumi).

5. Upacara Ngarot merupakan kenduri rakyat Lelea pada awal musim tanam padi yang menjadi arena pertemuan jodoh (secara simbolik) dan arena interaksi simbolik dua pertunjukan Ronggeng Ketuk dan Topeng (secara reflektif).

6. Upacara pasca-Ngarot (Mapag Tambadan Mapag Sri) merupakan proses interaksi simbolik masyarakat Lelea yang menyatu sebagai rangkaian tradisi menuju harapan rakyat untuk memiliki panenan yang melimpah.

7. Masyarakat Lelea adalah masyarakat pewaris aktif tradisinya dan pelaku interaksi simbolik dari seluruh rangkaian upacara pra-Ngarot dan pasca-Ngarot.

\section{Daftar Pustaka}

Anas Makruf

1966 Pengantar Antropologi Budaya. Djakarta: Pembangunan Djakarta 
Arthur S. Nalan

1999 Pesta Rakyat Jawa Barat (Suatu Kompilasi dan Analisa Fungsi). Bandung: STSI Bandung

Jakob Sumardjo

2000 Filsafat Seni. Bandung: Penerbit ITB

Polloma, Margareth M.

1987 "Sosiologi Kontemporer". Jakarta: Rajawali bekerjasama dengan Yasogama
West, Richard, Lynn H Turner (ed)

2007 Introducing Communication Theory: Analysis and Application, Third edition New York: McGraw Hill

Sumber lain:

1. Carminah (wawancara, 2006)

2. Warson (wawancara, 2009) 